\title{
3 \\ The global setting for Asian economic integration
}

\author{
Pascal Lamy
}

\section{Introduction}

East Asia has been part of the globalisation trend that has brought development to the Asian region as a whole, and reduced the vast numbers of people who were living below the poverty line. Globalisation has occurred as firms around the world have continually reallocated labour and capital to new and different uses in response to changing regulations, trade barriers and business opportunities. Increasingly, the tasks that these firms perform can be moved with relative ease to a different country or a different firm with a totally dissimilar process of production. Naturally, the efficiency created through this transformation is the direct consequence of industrial relocation and transfer.

A Ricardo-Schumpeterian model of trade illustrates how this process creates efficiency. Ricardo (1817) argued that manufacturing efficiency stems from greater international division of labour. Schumpeter (1942) described the ongoing process of remaking manufacturing systems as a 'gale of creative destruction', whereby less efficient structures give way to more efficient ones. These more productive systems take on the labour and capital 'freed up' by the transformation. 
This path of increased openness, with the reduction of cross-border barriers to trade leading to increased investment and trade flows and efficiency gains, has defined the globalisation of the past few decades. Much of East Asia's economic integration has occurred within this context.

The efficiencies created by the evolving international trade environment affect welfare in ways that are dependent on domestic social systems. As ever, policymakers must make it a priority that the economic gains from trade translate into social gains at all levels of society. Without such a focus, anti-globalisation sentiments will arise. We return to this imperative in this chapter's final section.

In the last few decades, most countries have reduced cross-border barriers, motivated by a combination of multilateral and regional commitments, as well as unilateral reform programs. As cross-border barriers have come down, and as production processes have become increasingly multilocalised, the frontier of multilateral trade governance has shifted to 'precaution' behind the border rather than 'protection' at the border. This refers to the harmonisation of value-based norms, and quality and safety-based standards that reflect citizens' collective preferences. It creates more opportunities for non-sovereign actors, such as corporations and non-government organisations (NGOs), to engage in the international trade system, a trend that is becoming more apparent. Multilateral and regional efforts need to ensure that they address the issue of standards.

Trade globalisation will keep changing. Growth in international trade volumes is projected to converge to a lower average rate globally by 2050 . Part of this slowdown is the result of lower expected gross domestic product (GDP) growth and investment, but it is also the result of a slower average rate of expansion of global value chains (GVCs) in recent years. Despite this reduced pace, international trade is not moving backwardsthe momentum remains towards further integration and multilocalisation of production.

Trade will continue with the changing nature of GVCs and the increased tradability of services. This is evident when trade is measured not by volume, but in terms of value added. This provides a more complex picture of the global trade environment, one in which service trades assume much greater importance and participation in GVCs that are linked closely to economic growth. These trends have affected, and are likely to continue to affect, the nature of East Asian economic integration. 
The remainder of this chapter is divided into four sections to discuss globalisation, which has been and will continue to be the setting for economic integration in East Asia. In the first section, the past pattern of globalisation is reviewed in the context of the Ricardo-Schumpeterian framework. The second section discusses the longer-term trends of multilocalisation and consumer protection, while the third section discuss the short-term trends, with a focus on whether there is a deglobalisation trend. Finally, the chapter presents concluding remarks regarding globalisation and the political context of trade.

\section{The Ricardo-Schumpeterian framework: Globalisation}

Historically, globalisation has been driven by technological progress; one early example is the invention of the steam engine and the drastic reduction in the cost and speed of transportation that followed. In recent decades, major technological revolutions, especially in information and communications technology, have resulted in vast reductions in the cost of trade. These technological revolutions increased economic growth by improving productivity.

Ricardo (1817) theorised that a system is at its optimum when each component is specialising in its area of comparative advantage. Schumpeter (1942), expanding on this process, argued that efficiency is created through confrontations that redefine each component's competitive position. Whether domestic or international, these confrontations between systems of production inherently lead to the reallocation of resources or 'creative destruction'.

International trade keeps moving forward, regardless of whether it is measured by volume or value added. As the Ricardo-Schumpeterian model illustrates, more efficient systems of production up-end and replace less productive ones-in other words, openness to trade works because it is painful and it is painful because it works. Individuals, firms and countries trade with the objective of becoming more efficient. Technological developments in transportation, logistics and information and communications technology have facilitated efficient multilocal value chains, which are cross-border in nature. 
The distribution of 'winners' and 'losers' from trade has changed over time. In part, this occurs because of the shifting positions of developing countries on GVCs (a subject that will be discussed further below); however, domestic social policies also play a role. For example, considering the example of the US, openness to trade can be considered only very minimally responsible for the continued stagnation of US manufacturing wages. Lawrence (2007) argued that the greater causes of stagnating pay cheques in the US are the increasing shares of wealth going to the population's top 1 per cent of earners, the amount of income going to corporate profits and the staggering increases in healthcare costs.

Bradford, Grieco and Hufbauer (2005, p. 73) estimated that an increase in US trade exposure by 10 per cent would increase the country's incomes by roughly 2 per cent. Therefore, it would be deeply counterproductive to attempt to mitigate wage stagnation by introducing trade barriers. Policymakers need to shift their focus to other areas to deal with the economic problems facing workers. Supranational institutions can do little to address wage inequality within individual countries or to repair their ailing health and welfare systems. These and related issues can only be addressed through domestic taxation and spending. Ultimately, if confidence in trade is to be rebuilt among a country's citizens, the right domestic policies must be in place.

\section{Longer-term trends: Multilocalisation and consumer protection}

Recently, discussions regarding world trade regulation have been dominated by inter- and intra-regional initiatives for integration, including the mega-free trade agreements, represented by the East Asia Regional Comprehensive Economic Partnership (RCEP), the TransPacific Partnership (TPP) and the Transatlantic Trade and Investment Partnership (TTIP). With the demise of the TPP almost certain, there has been a shift in focus towards bilateral agreements.

Trade agreements will continue to focus, in part, on required actions in relation to 'old-world' trade barriers, including tariffs, trade facilitation and distortions in agricultural policy. The Doha Round, which addresses many of these issues, is yet to be completed, notwithstanding the good progress made on trade facilitation in 2014 in Bali. Many developing 
countries and emerging markets continue to maintain high tariff rates. In most developing countries and, to an increasing extent, in some emerging countries, trade-distorting agricultural subsidies stand in the way of further integration.

Lowering trade barriers through such initiatives does indeed level the playing field of world trade and should continue to be prioritised. Yet, the nature of these barriers is changing with the transition to the 'new world' of trade. In the past, trade was characterised by domestic production processes and the focus of barriers was to protect producers. Hence, opening trade primarily involved lowering tariffs, subsidies and quotas; although this was far from easy, it was conceptually straightforward for negotiators.

However, a long-term trend, which is connected to multilocalisation, is the growing importance of consumer protection barriers. These new-world trade barriers are increasingly oriented towards precautionary, behindthe-border measures, rather than protectionary cross-border measures. This means a greater focus on the tastes and preferences of consumers rather than industries. Reducing these new-world barriers is more difficult because it necessitates the harmonisation of value-based standards across economies.

The progressive or graduated method of implementing trade openness, ${ }^{1}$ which is based on the level of development - and which has been successfully applied to old-world, producer-oriented trade barriers-does not always apply to new-world barriers. Although tariff reductions may vary in terms of the speed and the level of reductions depending on the level of development, this graduated approach is much harder to justify when attempting to reduce precautionary regulations across borders. For example, consider trade regulations regarding maximum pesticide levels on flowers grown for export. It makes little sense to have different maximum pesticide levels for flower-exporting countries based on income levels (see Lamy, 2015a).

1 That is, to use the terminology of the multilateral trading rules in the World Trade Organization (WTO), 'special and differential treatment'. 
The implementation of new-world trade regulation transforms the analysis of the implications of bilateral and multilateral initiatives because the central critique of bilateralism-that it is preferential and discriminatory-is invalid for precautionary regulation. Bilateral equalisation of safety regulations in the US and the EU would not be discriminatory. Indeed, exporters in both markets would benefit.

At the same time, the success of developing countries' exports still hinges on the efficacy of international regulatory institutions. This remains the case in East Asia, as well as in Eastern Africa and Central America, despite the relative success and growing influence of intra-regional integration projects.

The multilocalisation of production processes increases the opportunities for non-sovereign actors to engage in the process of lowering barriers to trade. Consider again the example of standards for maximum pesticide residue levels in flowers. A Rwandan exporter of flowers would benefit substantially if countries such as the US or Japan adopted the same regulatory standards as in Rwanda. Different levels of regulation force exporters to segregate their production based on market destinations, which prevents them from achieving economies of scale and reaching their potential comparative advantage. Moreover, it is unlikely that trade negotiators will be responsible for determining the maximum levels of pesticide residues permitted in flowers, as this task would be allocated to phytosanitary experts, informed by research on the health effects of pesticides. This illustrates one way in which the scope for private actors and NGOs to act in harmonising trade regulations will increase with the pace of multilocalisation.

This shift in agency reflects the discrepancy between the potential efficiency of the Westphalian system, which is treaty- and convention-based, and the bottom-up, GVC-based introduction of social standards to international trade. In future decades, the environmental and social standards of supply chains could become even more significant for workers' conditions than the classical international trade regime. This should be borne in mind in the forthcoming regional and bilateral trade arrangements that are part of the East Asian process of economic integration.

In addition, multilocalisation and the expansion of GVCs means that governments must rethink how best to pursue trade-led growth in ways that are both effective and fair. Government guidance can help instil a 'virtuous circle' of competitiveness and trade growth, with implications 
for continued development. For developing economies, public-private cooperation attracts foreign direction investment (FDI) and, with it, new technology. Foreign investment in infrastructure, along with the support services required to successfully pursue such investment, can bolster ties between countries. Ultimately, this may result in greater GVC participation. For these mechanisms to be effective, active policies regarding labour, innovation and education are indispensable.

\section{Short-term trends: Is there a deglobalisation trend?}

Despite the recent deceleration, growth and trade are now increasing globally, and it is likely that they will continue to do so, especially in developing economies and emerging markets. The growth of the global economy is expected to pick up slightly, to 3.5 per cent in 2017, and it is expected to stabilise at around 3 per cent per year over the next 50 years. Emerging markets and developing economies should grow at a rate of close to 4.5 per cent in 2017 and reach 5 per cent in 2022, compared with growth rates of 1.7 per cent in Europe and 2.3 per cent in the US in 2017, which are expected to reach 1.5 and 1.7 per cent, respectively, in 2022. Emerging and developing economies in East Asia are expected to continue to achieve the highest growth rate, remaining at 6.4 per cent growth in 2017, despite the slowdown in China. India and a number of the Association of Southeast Asian Nations (ASEAN) countries are experiencing high growth of 7-8 per cent and it is projected that this region will grow at 6.3 per cent in 2022. Thus, East Asia will remain the emerging world's engine of growth in coming decades (International Monetary Fund [IMF], 2017).

International trade growth, as measured by volume, could rebound briefly to 3.8 per cent in 2017 . A healthy level of trade volume growth of around 3 per cent can be expected over the next 15 years. It seems unlikely, however, that the global economy will return to the steep trade growth path experienced prior to the global financial crisis (GFC) in the next decade (IMF, 2017) (see Table 3.1).

East Asian economies are some of the world's most integrated economies, along with those of the EU. In East Asia, almost 50 per cent of the region's trade is intra-regional. Five of the world's six fastest-growing export economies are Asian; they are expected to experience export 
growth of 8-11 per cent annually from 2014-30. In addition, the rising global trade share of the emerging economies will bolster the expanding trade between developing countries. South-south trade proved uniquely resilient to the GFC. Real growth in south-south trade is predicted to be close to 6 per cent each year in the period up to 2030-nearly double the global average (Lamy, 2015b). This has resulted in an increase in the developing countries' share of world trade. The share of today's advanced countries (the EU, US, UK, Japan and Canada) is expected to decline from 48 per cent in 2012 to 37 per cent in 2030 and to 33 per cent in 2060 (Figure 3.1). Shares of global trade are changing to account for greater shares of south-south and north-south trade (Figures 3.1 and 3.2).
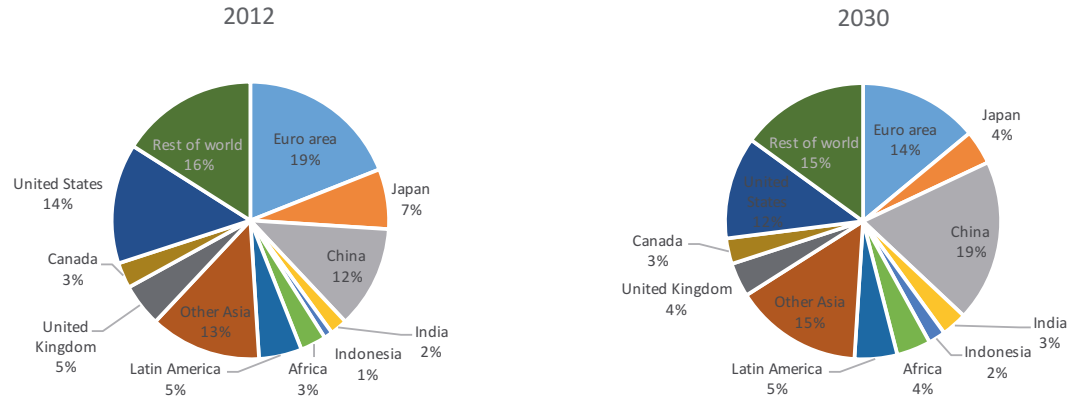

2060

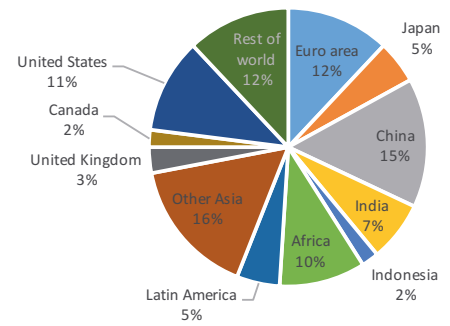

Figure 3.1: The changing distribution of global trade (exports as a share of global exports)

Source: Projections from Château et al. (2014). 


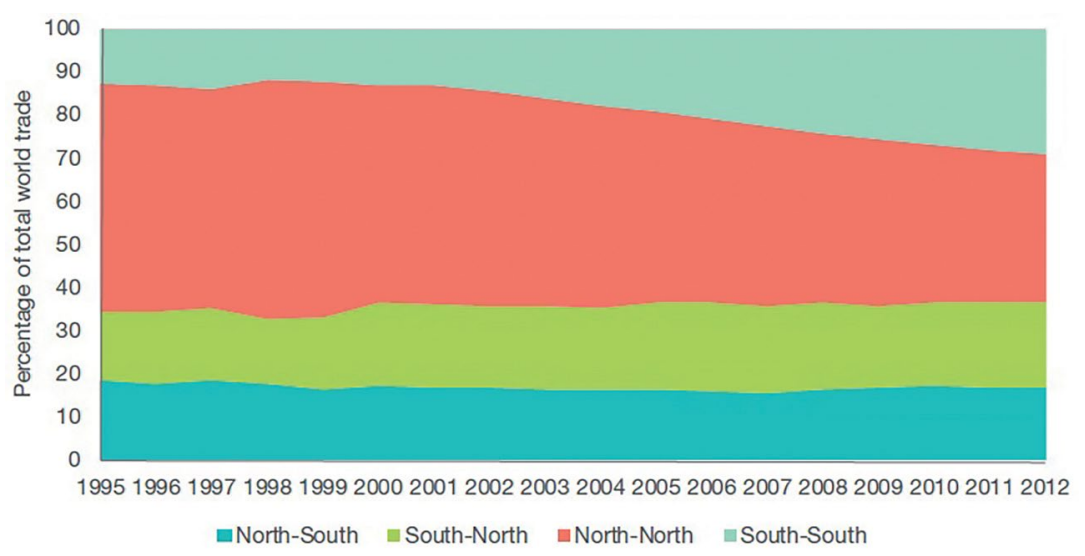

Figure 3.2: The south-south trade corridor, 1995-2012

Note: For each pair of regions, the figures represent exports from the first region to the second.

Source: United Nations Conference on Trade and Development (UNCTAD, 2014, p. 34).

Emerging economies are attracting an ever greater share of global FDI flows. Although it can be difficult to develop long-term predictions of FDI flows, the strong correlation between FDI and trade indicates that it is likely that FDI flows will continue to follow trade flows in being reoriented towards developing economies (Lamy, 2015b, p. 134). However, trade volumes alone cannot tell the whole story when it comes to changes in the global trade environment. International trade is growing slowly not only because of slow GDP growth following the GFC, but also because of structural change that has occurred in the trade-GDP relationship in recent years.

The recent relative decline in trade growth by volume has resulted from a slowdown in the expansion of GVCs and the faltering performance in reducing obstacles to trade. However, this slowdown indicates very little about the effect of trade on growth. It is not necessarily the case that the slowing of global trade-or, to be precise, the slowing of the increase of international trade volume-will lead to weaker global growth once the effect of value added on the trade numbers is taken into account (Lamy, 2015b, p. 139). Measuring trade by volume estimates the end point effect of GVCs, whereas measuring trade in value added provides estimates of trade as a driver of growth. The latter is what ultimately matters most. 
Research based on measuring trade in value added has established that private-sector competitiveness and export performance increasingly depends on openness and participation in GVCs (i.e. Organisation for Economic Co-operation and Development [OECD] 2016). Services, in particular, add substantial value to manufacturing exports through their role in value chains. Indeed, the facilitation of services imports is one of the most effective ways for economies to boost the value of their manufacturing exports.

Intermediate goods often cross borders several times during the production stage. This can lead to miscounting and statistical errors in estimating trade volumes, whereas measuring with value added avoids these problems. It also helps to track commercial value at each country's point of entry, helping to distinguish when countries are simply re-exporting foreign components. Moreover, value addition can be decomposed into assets that are particular to the exporting industry, as opposed to the valueadded contributions made by domestic suppliers.

The value-added measurement of trade enables more precise bilateral trade balance figures for analytical purposes. Conventional measurement by trade volume assigns all value to the final link in the production chain, even if the value added at this final stage was relatively minor. Take the wellknown example of the iPhone-if measured conventionally, 100 per cent of the phone's value is counted at its assembly in China, deepening the US trade deficit by that amount when the phone is imported into the US. The phone's actual effect on China's GDP, in contrast, is around 5 per cent of that value (Lamy, 2013b).

Table 3.1: Average trade growth by volume, value and unit value (per cent)

\begin{tabular}{|l|c|c|c|}
\hline Period & Volume & Unit Value & Value \\
\hline $1981-1985$ & 2.9 & -3.5 & -0.7 \\
\hline $1986-1990$ & 5.8 & 6.2 & 12.3 \\
\hline $1991-1995$ & 6.2 & 1.9 & 8.4 \\
\hline $1995-2000$ & 7.0 & -2.1 & 4.8 \\
\hline $2001-2005$ & 5.0 & 5.1 & 10.5 \\
\hline $2006-2010$ & 3.7 & 4.6 & 9.0 \\
\hline $2011-2015$ & 3.1 & -1.3 & 1.8 \\
\hline $2013-2015$ & 2.6 & -6.0 & -3.6 \\
\hline
\end{tabular}

Source: World Trade Organization Secretariat (2016). 
What can one learn from measuring trade by value added? First, it provides a sectoral picture of trade that differs substantially from the conventional approach. This can be seen most clearly in the share of services in global trade. Services have been referred to as the 'poor relation of globalisation'-agriculture, which accounts for just 7 per cent of trade, often attracts greater attention than services (Lamy, 2013b).

However, services play an indispensable role in value chains, whether domestic or international. This is because the services that drive value chains-whether information technology, logistics, marketing or distribution-are most likely to be subcontracted to an external firm.

If measured by value added, the proportion of services in global trade is nearly twice that measured by volume. For 2008, immediately before the GFC, services accounted for 23 per cent of total trade when measured in the traditional way; however, this increases to 45 per cent if the direct and indirect value added ascribed to services is incorporated. For 2013, services were the chief contributors to global trade, whereas the manufacturing industry's share of international trade declined proportionally (Lamy, 2013b).

Examining value-added trade reveals that there are more actors in the supply chain, particularly smaller suppliers and subcontractors, than are often imagined. In contrast, the volume-based statistics appear to reduce the production process to a few massive players, such as the aeronautical, pharmaceutical and automotive industries.

The contribution of services to export value is most significant in advanced economies. Further, the services sector is where an increasing share of jobs is being created. This is a significant development because it pertains to developed countries' comparative advantages. The competitiveness and sophistication of advanced economies' services, including management, logistics and research and development, is crucial to their comparative advantage in trade.

Another perspective offered by the value-added account of global trade is that effective importers can often make the best exporters. If an industry's competitiveness hinges substantially on the suppliers and subcontractors that are integral to its production process, it is in that industry's interest to continually improve its access to high-quality services. 
The emerging economies' trade growth in recent years has been highly dependent on their rapid integration into GVCs, including through services provision. Between 1990 and 2010, the share of developing countries in global value-added trade rose from 20 to over 40 per cent. More than half of all the exports of the emerging economies are related to participation in GVCs. In particular, south-south global linkages are growing rapidly and, over the last 25 years, the proportion of trade between developing countries that is related to GVCs has quadrupled (Lamy, 2015b).

Most developing regions are increasing their participation in GVCs at a much faster rate than advanced economies. Consequently, many of the 25 highest-ranked economies in terms of GVC participation are developing countries. East Asia, in particular, is the world's leading region in terms of GVC participation because of its dominance in the processing of export-oriented manufactured goods (Lamy, 2015b).

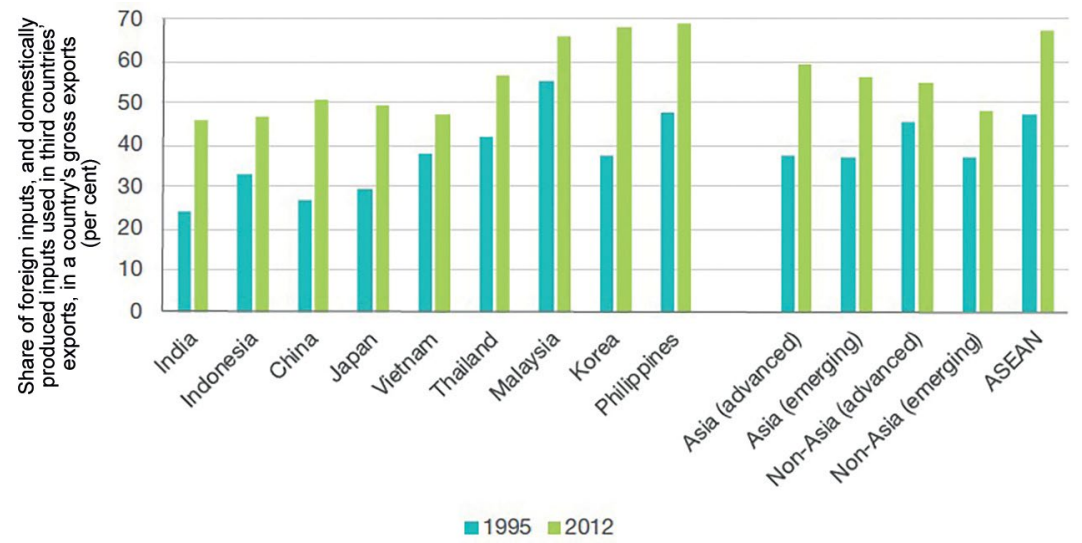

Figure 3.3: Emerging economies' participation in global value chains, 1995 and 2012

Note: Non-Asia includes comparable advanced and emerging economies.

Source: Cheng, Rehman, Seneviratne and Zhang (2015, p. 6).

South Asia remains the region with the lowest participation in GVCs. A major share of South Asian service exports serve domestic demands. Nonetheless, South Asia also has the world's highest growth in GVC participation, although this is from a low base (Lamy, 2015b). 
Countries can be defined as either upstream or downstream in GVCs, with upstream countries furthest from final demand and downstream countries closest. Upstream countries are more likely to produce components and inputs, whereas downstream countries focus more on product assembly. A number of East Asian economies have succeeded in moving upstream through specialisation, particularly China, the Philippines, Malaysia and Singapore. These Asian economies have seen exceptional growth in the values of their initial inputs, with increases of over 8 per cent during 1995-2008 (Lamy, 2015b, p. 141).

Today, partly as a result of the expansion of GVCs, countries tend to specialise in particular business functions - that is, roles in the supply chain — rather than in individual industries.

These trends in GVC development are expected to continue, with East Asia remaining a key part of their evolution. In the next stages of the East Asian economic integration, these trends in GVC development, including the important role of services, should be kept in mind.

Recent contractions in trade have sometimes occurred because of a lack of access to trade finance, or heightened perceptions of risk brought on by the GFC, which has caused producers to swap from international to domestic suppliers. This process of domestic-focused consolidation suggests that there is an 'optimal level of fragmentation' (De Backer \& Miroudot, 2013). At the same time, there is not yet sufficient evidence to determine whether cyclical or structural factors are behind recent GVC contractions. The flexibility of GVCs during the financial crisis is a positive sign for medium-term trade growth. This is especially the case for regions such as Africa, where trade intensity is set to increase.

Although the expansion of GVCs is slowing-particularly in advanced economies - international trade is still tending towards longer and more specialised value chains.

The growth of a country's exports is highly correlated with its participation in value chains through the import of inputs and intermediate goods. This relationship is particularly strong for emerging economies, but it is also important for industrial powers, such as Germany. The ability to import relatively inexpensive intermediates frees up domestic firms at the margin to invest in their areas of greater comparative advantage. This enables advanced economies, including the US, Europe and Japan, to specialise further in providing value chain-based services, such as research and 
development, and industrial engineering, creating jobs in these countries rather than destroying them. Indeed, investment in these kinds of services generates particularly high-paying jobs (Lamy, 2013b).

\section{Globalisation and the political context of trade}

The Ricardo-Schumpeterian model of international trade has been pushed to extremes by three things: the sheer scale and disruption of economic shocks, the high and growing number of actors, and the political limits confronting certain trade concessions (e.g. agricultural subsidies in the US and Japan). This is political economy in its fullest sense: the negotiators are negotiating with themselves.

These political limits are even harder to navigate in times of crisis when economies are more fragile. The agency of negotiators declines as a result (Lamy, 2012). It is natural that the process of trade liberalisation and growth raises concerns of fairness, sustainability and social justice. Trade integration leads to growth by up-ending and reshaping the global web of production, creating new efficiencies; however, the way that these efficiencies translate into welfare depends, as ever, on responsible social policies, usually at the domestic level. It is crucial that governments play a leading role in ensuring that trade liberalisation works in the interest of all income levels, especially in developing countries. I have previously referred to this imperative of 'free trade for all' as the 'Geneva consensus' (see Lamy, 2013a).

A discrepancy exists between the benefits of globalisation and the legitimate values shared by diverse communities. The gains of globalisation tend to accrue in favour of large firms and economies, simply because of the economies of scale that are linked to competitiveness in trade. In contrast, the utility that stems from identity and cultural and political legitimacy comes from closeness, rather than openness, and from uniqueness, rather than from scaling up to large volumes of production for export.

The recent wave of Western populism has resulted partly from socioeconomic disruptions, the costs of which are relatively widely known and studied, and partly from cultural disruptions. These disruptions are largely unexplored in the literature on international trade, even though international trade is often blamed for the disruptions. Therefore, it is 
imperative that policymakers' agendas should turn to the broader question of how best to mitigate social and cultural insecurity. In formulating trade and social policy, these insecurities must be given careful consideration if the legitimacy of policymaking in these areas is to be preserved.

Even if the pace of globalisation slows, 'deglobalisation' is not likely to occur. Technological progress, the key driver of globalisation, has never regressed. The clock cannot be turned back, nor would this even be desirable. Turning our backs on globalisation would do nothing to address the biggest issues facing the world, which range from climate change to nuclear proliferation to economic inequality. Severing economic and cultural linkages cannot meaningfully improve employment.

The central problem with globalisation is one of insufficient governance. In the nineteenth century, the first age of globalisation disintegrated because of the lack of coherent political and policy responses in the face of unprecedented social and economic changes. Similarly, the threats confronting today's global economic order are political in nature.

The need to reinvent international institutions is one challenge in addressing these problems. The birth of the Group of Twenty (G20) in place of the Group of Eight (G8) was a great innovation and signified that the international system could adapt to change. More broadly, the scope and capacity for international cooperation has never been so significantwhether stopping pandemics or rewriting technical standards, tackling drug trafficking or combating deforestation. Yet, it has not been sufficient to date. Transforming our institutions will not just be about building new ones, but about 'networking' the existing organisations in a more effective way. Increasingly, the United Nations, the WTO and the IMF must operate as a coherent whole (see Lamy, 2011).

Policymaking has become more complex as international integration has advanced. For example, negotiations on climate change concern international economics as well as the environment. How are the technologies, costs and benefits of environmental policy to be distributed? Similarly, the push to further integrate developing countries into the global economy requires a focus on building the capacity of those countries, far beyond the passive imposition of a set of financial rules. These issues are not just international—more coherent policy must also be a domestic aim. 
There is much to be done to strengthen the legitimacy of the global system - to build trust and better align these institutions with societies' interests. This will mean designing and implementing policies for a globalised world, in which education, training and income distribution are prioritised. Deliberation over the most significant causes of wage stagnation (e.g. trade or technology) obscures the more important fact that people in advanced and developing countries need more assistance in coping with profound economic transformations. People will only continue to support globalisation and openness if they share in its benefits. These are all lessons that East Asia should bear in mind as its process of economic integration continues.

\section{References}

Bradford, S. C., Grieco, P. L. E. \& Hufbauer, G. C. (2005). The payoff to America from global integration. In C. F. Bergsten (Ed.), The United States and the world economy: Foreign economic policy for the next decade. pp. 65-109 Washington, DC: Peterson Institute for International Economics. Retrieved from: www.piie.com/publications/chapters preview/3802/2iie3802.pdf

Château, L. F., Fouré, J., Johansson, Å. \& Olaberría, E. (2014). Trade patterns in the 2060 world economy. OECD Economics Department Working Paper No. 1142. Paris, France: OECD Publishing. dx.doi.org/ 10.1787/5jxrmdk5f86j-en

Cheng, K., Rehman, S., Seneviratne, D. \& Zhang, S. (2015). Reaping the benefits from global value chains. IMF Working Paper No. 15/204. Washington, DC: IMF. Retrieved from: www.imf.org/en/Publications/ WP/Issues/2016/12/31/Reaping-the-Benefits-from-Global-ValueChains-43311

De Backer, K. \& Miroudot S. M. (2013). Mapping global value chains. OECD Trade Policy Paper No. 159. Paris, France: OECD Publishing. dx.doi.org/10.1787/5k3v1trgnbr4-en

International Monetary Fund (IMF). (2017). World economic outlook April 2017. Washington, DC: IMF. Retrieved from: www.imf.org/ en/Publications/WEO/Issues/2017/04/04/world-economic-outlookapril-2017 
Lamy, P. (2011). Lamy underlines need for 'unity in our global diversity'. Speech presented at the Centre for Strategic and International Studies, Jakarta. Retrieved from: www.wto.org/english/news_e/ sppl_e/sppl194_e.htm

Lamy, P. (2012). Has international trade reached a deadlock? Interview, Knowledge@Wharton, Wharton School of the University of Pennsylvania. Retrieved from: knowledge.wharton.upenn.edu/article/ has-international-trade-reached-a-deadlock-an-interview-with-pascallamy-director-general-of-the-wto/

Lamy, P. (2013a). The Geneva consensus: Making trade work for all. Cambridge, England: Cambridge University Press.

Lamy, P. (2013b). The new mapping of international trade. Speech presented at École Polytechnique Fédérale de Lausanne. Retrieved from: www.wto.org/english/news_e/sppl_e/sppl267_e.htm

Lamy, P. (2015a). The role of aid for trade and technical trade assistance in regional economic integration. International Trade Forum Magazine, 2(12), 28-29.

Lamy, P. (2015b). Where will emerging markets stand in global trade? In H. S. Kohli (Ed.), The world in 2050, pp. 133-167, Oxford, England: Oxford University Press.

Lawrence, R. Z. (2007, 15 June). Slow wage growth and US income inequality: Is trade to blame? Paper presented at the 'Is free trade still optimal in the 21st century?' conference, Brandeis University. Retrieved from: sites.hks.harvard.edu/fs/rlawrence/Lawrence\%20for $\% 20$ Brandeis.pdf

Organisation for Economic Co-operation and Development (OECD). (2016). Re-thinking upgrading: Benefitting from participation in global value chains. OECD Trade Policy Notes, October. Paris: OECD. Retrieved from: www.oecd.org/tad/policynotes/benefittingparticipation-gvcs.pdf

Ricardo, D. (1817). On the principles of political economy and taxation. London, England: John Murray.

Schumpeter, J. (1942). Capitalism, socialism and democracy. New York, NY: Harper \& Brothers. 
ASIAN ECONOMIC INTEGRATION IN AN ERA OF GLOBAL UNCERTAINTY

United Nations Conference on Trade and Development (UNCTAD). (2014). World economic situation and prospects (WESP/2014). Geneva: UN Publications. Retrieved from: www.unctad.org/en/pages/ Publication Webflyer.aspx?publicationid=771

World Trade Organization Secretariat. (2016). World trade statistical review. Retrieved from: www.wto.org/english/res_e/statis_e/wts2016_el wts2016_e.pdf 
This text is taken from Asian Economic Integration in an Era of Global Uncertainty, edited by Shiro Armstrong and Tom Westland, published 2018 by ANU Press, The Australian National University, Canberra, Australia. 